\title{
The relationship between social responsibility of organizations with their financial performance (Case study: financial organizations and institutions of Guilan province)
}

\author{
Mir Seyed Mozaffar Mirbarg Kar ${ }^{1}$, Seyed Jalil Arayesh Shokooh ${ }^{2}$ \\ ${ }^{1}$ Faculty of Islamic Azad University of Rasht Branch \\ ${ }^{2}$ M.A Management, Islamic Azad University of Rasht Branch \\ E-mail address: seyedjalil49@yahoo.com
}

\begin{abstract}
Keywords: social responsibility, performance of organizations and institutions, financial performance, organizations and financial institutions of Guilan province.
\end{abstract}

\begin{abstract}
Subject of social responsibility and its impact on financial performance of organizations and institutions are issues that always taken into consideration in the world of research. In this study, researchers sought to test the relationship between these two variables . Due to this, the main object of the current study was to investigate the relationship between social responsibility and its dimension and financial performance in financial organizations and institutions of Guilan province. Survey method was practical and in terms of data collection was descriptive. The statisyical population include all organizations and financial institutions of Guilan province and samples were selected through census sampling and data collection tool was a standard questionnaire. Testing hypotheses, Pearson's correlation coefficient was used and multiple linear regression and Friedman test was used for further analysis. SPSS statistical software was used to analyze the data. The results showed that there is positive and significant relationship between social responsibility dimensions and financial performance of the organizations and financial institutions Guilan province.
\end{abstract}

\section{INTRODUCTION}

Organizations and institutions are responsible for the success and continuity of life depends on the social environment. In this case, with the prospective approach, social responsibility not only it will not regarded as a expensive- policy, but also is regarded as a human and social investment and (Heydariyan, 1389). On the other hand, economic efficiency is not regarded as the only responsibility of organisations and institutions. As organizations and institutions effect society with their services, society also organizations and institutions are obliged to the sense of responsibility against their performance in order to observe desired services, as well as the social considerations (Ghaheri,1389). So, organizations and institutions have to do activities that is acceptable of society and in accordance with the values and dont harm the society, and if it incured the relevant organizations and institutions have to compensate it (Santos et al., 2011). In other words, if organizations and institutions want to maintain their position society and to act in a way that to cause survival, development and their success, it is necessary to revise its performance and to fulfill his own commitments to the citizens (clients) (Liang \& Chen, 2011). Subject of financial performance and social responsibility is one of the issues that has always been in dispute between theorists.In spite of high acceptance of social responsibility of organizations and institutions, there is conflict in policies of social responsibilty in tactical and strategies decisions.Criticizers believe that the social responsibility of organizations and institutions have ambigues structure and managers are unable to determine their social responsibilities. social responsibility increase operational costs and destroy shareholder wealth. The main concern of critics of the social responsibility of businesses, the costs associated with improving the social performance of organizations and institutions may be further their interests.

On the other hand, researchers such as Spicer(1987), Porter and Van der Linde (1995), Brun and others(2000) suggest a long list of benefits of social responsibility of organizations and institutions 
and claim that social responsibility initiatives can lead to the good benefits and improvements in confidence Investors, efficient use of resources and new market opportunities, all of which can be understood by the capital markets. The social responsibility of organizations and institutions may reflect the innovation and initiative that obligate structural change in the production and distribution processes and providing services (Yazdani, 1388). Insistance and desire of commercial units in terms of commitment to social responsibility in all dimentions have significant effect on financial performance (Sandhu \& Kapoor, 2010). As a result, businesses unit can maximize long-term outputs by reducing kegative effects on society, optionally(Samy et al,2008). Studies, suggest that because the general position of organizations and institutions in the community is very complex, there isn't direct relationship between social responsibility and financial performance of organizations and institutions (Tsoutsoura, 2004; Simpson\& Kohers, 2002). In the current study, with respect to a presentation on the relationship between social responsibility and financial performance of organizations and institutions, researcher intends to examine the effect of the dimensions of social responsibility on financial performance in organizations and financial institutions of Guilan province. Indeed, financial performance is one of the biggest problems that organizations and institutions of inside the country faced. On the other hand, parameters that shows the organizations and institutions are loyal to their social responsibility, we see less in society. Accessing to the proper solutions to boost the competitive capabilities and performance are considered as the main concern of the organizations and institutions. Hence the present study attempted to clarify this issue, which is: Is there relationship between social responsibility of organizations and financial institutions of Guilan province with its financial performance?

\section{THEORETICAL REVIEWS}

Increasing the efficiency and services are the main objectives of the organizations and institutions. In the information era and globalization, organizations and institutions respond effectively in order to achieve the objectives of social expectations and moral judgments and in the best way these expectations with the economic goals of integration of organizations and institutions to make possible the higher goals. The social responsibility of organizations and institutions are a key factor of their survival(Lee,2011). In recent years, the theory was stated that, businesses unit can create wealth, employment and innovation, guarantee the market, strengthen their activities and improve their competitions, if they have a major role to maintain their social (Sandhu \& Kapoor, 2010). Carrie and Ross(1997) found that customers expect business units to observe ethics in business units. Moher and Web 5 (2005) also proved that customers prefer to work more with organizations and institutions that are aware of their social responsibility (Mohr \& Web,2005). Peter Drucker 1, one of the most prominent experts in the management says organizations and private institutions must also accept that have public and social role in order to maintain its legitimacy and survival in the environment. The social role of this principle accepted originated from that "everyone is responsible for their behavior and if his behalf, whether intentionally or unintentionally, harm to another, he must be accountable." Organizations and institutions are not excluded from this category and must respond to their adverse social effects. Organizations and institutions have a major impact on the social system and therefore how they should be operate such that it does a disservice to the community, if losses, organizations and institutions are required to compensate it. In other words, organizations and institutions should not to be independent of the external environment so-called unique, but should be part of a whole, that is, the environment, but also to a whole that is environment in consistent with the aspirations of the social environment and welfare society.

Badaver Nahandi and colleagues (1393) investigated the relationship between social responsibility and the performance of accepted companies in Tehran Stock Exchange. The results showed that after controlling size of organizations and institutions, financial leverage and systemic risk, there is a significant and positive relationship between social responsibility and the performance of organizations and institutions. Poor Ali and Hajjam (1393) investigated the relationship between social responsibility disclosure and institutional ownership of listed companies in Tehran Stock 
Exchange. The findings suggest a negative relationship between social responsibility disclosure, the disclosure of information on directors relations, production and the environment with institutional ownership. However, there is no significant relationship between disclosure of social participation information and institutional ownership. Arab Salehi et al (1392) investigated the article with the title of relationship between social responsibility with the financial performance of the companies accepted on the Stock Exchange of Tehran . Research results showed that there is relationship between the financial performance with social responsibility of organizations and institutions in customers and existing institutions in society.But there is no relationship between financial performance and social responsibility of institutions and organizations than staff and the environment. The study will help managers to effective policies related to social organizations and institutions that development is necessory responsibility for their better access to financial performance in the long - term. Also, they will provide a vision for organizations in the field of role of social responsibility in the future gains.Senobar et al (1390) examined the relationship between social responsibility and financial performance of the companies. The results showed that there is no relationship between social responsibility and each of the five components of it with financial performance variable. Also, there is positive and significant relationship between the size and risk of organizations and institutions with financial performance.Penn and his colleagues (2014) demonstrated a survey as a relationship between joint social responsibility and financial performance in the mining industry: mining companies in China. The results showed that the difference in the relationship between joint social responsibility and joint financial performance is based on industry characteristics. Flamer (2013) investigated the research that will the social responsibility lead to better financial performance? This paper examines the impact of joint social responsibility on financial performance. Finally, it was determined that the impact on the organizations and institutions working in industries are stronger than higher fundamental principles of social responsibility. Kanval et al (2013) studied the impact of joint social responsibility on the financial performance of the company, and the concept of joint social responsibility of organizations and institutions has made significant contributions over the past decade in Pakistan, while there was significant important international data between joint social responsibility and financial performance of organizations and institutions. The results showed that there is positive and significant relationship between joint social responsibility and financial performance of organizations and institutions. organizations and institutions in which use the joint social responsibility not only they benefit from ongoing development but also enjoy improved financial performance. Wangy (2013) studied the relationship between activities of joint social responsibility and financial performance of organizations and institutions in the manufacturing, construction and the Nairobi Stock Exchange. Literature shows contradictory results about the relationship between joint social responsibility and financial performance of organization, in which some studies show a positive relationship and some indicated negative relationship. Still others suggest that there is no relationship between two variables. The results showed a positive and significance relationship between joint social responsibility and financial performance. Fuazy and Edris ( 2010) investigated the relationship between joint social responsibility and financial performance: new evidence from Indonesian companies. He concluded that there is significant and positive relationship between financial performance and joint social responsibility regarding to theoretical resources and the theory of good management of resources. According to the backgrounds of internal and external researchers, it can be generally said that, in all research that has been in the history of research in this study, the variable of social responsibility is as a factor have positive and significant impact on financial performance of the research was done by researchers, were confirmed. The point to be noted in this case, according to the researchers who each case was different, in spite of this difference, it has confirmed significant and positive impact of social responsibility on financial performance. 


\section{The main objective of the study}

Measurement of the relationship between social responsibility of financial organizations of Guilan province with their financial performance.

\section{Sub-goals}

Measurment of the relationship between delegation of authority to employees in the financial organizations of Guilan province with their financial performance.

Measurment of the relationship between internal communication by right solutions for improvement of efficiency in the financial organizations of Guilan province with their financial performance.

Measurment of the relationship between employees participation in decision making in the financial organizations of Guilan province with their financial performance.

Measurment of the relationship between flexiblity in the financial organizations of Guilan province with their financial performance.

Measurment of the relationship between to supportive management in the financial organizations of Guilan province with their financial performance.

\section{Main hypothesis}

There is positive and significant relationship between social responsibility of financial organization of Guilan province with their financial performance.

\section{Sub-hypothesis}

There is positive and significant relationship between delegation of authority to the employees and financial performance in the financial organizations of Guilan province.

There is positive and significant relationship between internal communication with the right solutions to improve the efficiency of financial institutions Guilan province.

There is positive relationship between participation of employees in decision-making with financial performance in Guilan province.

There is positive relationship between flexibility of the financial organization of Guilan province with their financial performance.

There is positive relationship between supportive management with financial organizations of Guilan province with their financial performance

\section{Methodology}

Many factors are associated with the financial performance in which one of the factors is social responsibility. Over the past three decades, organizations and institutions experienced increasingly pressure. Some believe that social responsibility is a costly obstacle. While some believe that the methodology of this responsibility is as a strategic tactic to gain markets (Ahmed et al, 2012). This conceptual model retrieved from, 2008 Abrunhos \& sa the model. In this model, the dimension of social responsibility, that is, delegation, internal communication, employee participation, flexibility and supportive management as a independent variable and the financial performance of organizations and institutions has been considered as the dependent variable. Relationships between variables in the model of Figure (1) is shown 


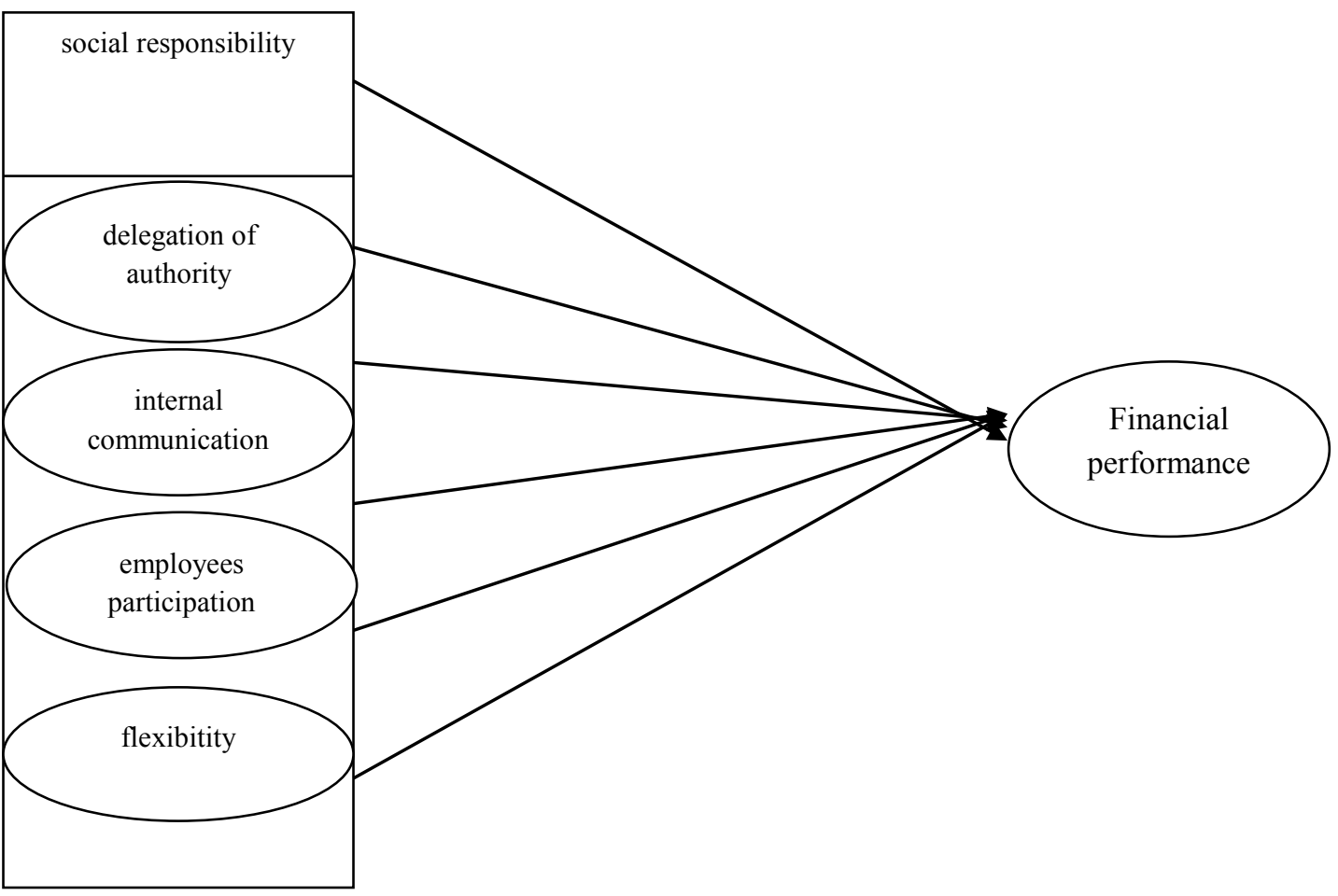

Figure 1. Model (Abrunhosa \& Sa, 2008)

In terms of time, is a cross-sectional study in which the observations is done in a short period of time in which data collection. In terms of data collection is field and in terms of depth is also wide. The population of study included all organizations and financial institutions of Guilan province. To select a sample, census method was used.

Gathering data from the standard questionnaire, and this questionnaire distributed among 150 managers and financial experts. In determining the validity, content validity has been used. Judging professors and experts studied the issue for consideration. Investigating reliability of questionnaire Cronbach's alpha coefficient was used. The Cronbach's alpha between individual items correlation with the total score of tools taken. Initially, 37 questionnaires were distributed and Cronbach's alpha for the review of each of the variables and, ultimately, Cronbach's alpha coefficient of the questionnaire was calculated. The results of the calculations in Table 1 was shown. Since Cronbach's alpha of 7.0 from each of the variables, as well as whole questionnaire Cronbach's alpha was calculated 0.863 , so reliability was confirmed.

\begin{tabular}{|l|l|}
\hline Variables & Cronbach's $\boldsymbol{\alpha}$ \\
\hline Delegation of authority & 0.778 \\
\hline Internal communication & 0.781 \\
\hline Employees participation & 0.732 \\
\hline Flexibility & 0.706 \\
\hline Supportive management & 0.721 \\
\hline Finanacial performance & 0.790 \\
\hline All Items & 0.863 \\
\hline
\end{tabular}

\section{RESULTS}

The results of the descriptive analysis showed that the average independent variable, delegation is above average. The mean and standard deviation of the this index were respectively 3.9983 and 0.86287. Given that the average expected in the Likert (five options), the evaluation respondents indicated that mean all the items related to the variable delegation is above average. 
The average independent variable of internal communications is above average. The mean and standard deviation of the index is respectively 0.8567 and 0.69956. Assessment respondents indicated that mean all the items related to the variable internal communications, higher than average. Average employee contributions independent variable, the average is Balart. The mean and standard deviation of the index is respectively 3.8983 and 0.71986. Assesment of respondents indicated that the average of all items related to employee contributions, higher than average. The average independent variable flexibility, higher than average. The mean and standard deviation of the index respectively 4.12 and is 0.82357 . Evaluation of respondents indicated that mean of all the items related to the flexibility variable are higher than average. Mean of supportive management of the independent variable is higher than average. The mean and standard deviation of the index is respectively 4.2167 and 0.93482 . Assessment respondents indicated that mean all the items related to the variable of supportive management is higher than average. Average variable of financial performance was higher than average. The mean and standard deviation of this index is respectively 4.0833 and 0.81758 . Assessment respondents indicated that the average of all items related to the variable of financial performance are higher than average.

\subsection{Results of testing hypotheses}

H1: There is positive and significant relationship between delegation of authority to the employees and financial performance in the financial organizations and institutions of Guilan province.

Table 2. Correlation coefficient between delegation of authority to managers and financial performance

\begin{tabular}{|l|l|l|l|}
\hline \multicolumn{2}{|c|}{} & \multicolumn{1}{|c|}{$\begin{array}{c}\text { Delegation of } \\
\text { authority }\end{array}$} & \multicolumn{1}{c|}{$\begin{array}{c}\text { Financial } \\
\text { performance }\end{array}$} \\
\hline $\begin{array}{l}\text { Delegation of } \\
\text { authority }\end{array}$ & Pearson Correlation & 1 & 0.701 \\
\cline { 2 - 4 } & Sig.(2- tailed) & & 0.000 \\
\cline { 2 - 4 } & $\mathrm{N}$ & 150 & 150 \\
\hline
\end{tabular}

Pearson correlation coefficient of 0.701 with significance level of 0.000 is obtained because the significant level is lower than $0.05, \mathrm{H} 1$ is confirmed. So, there is positive and significant relationship between delegation of authority to elmployees and financial performance in financial organizasions and institusions of Guilan province. After calculating the correlation coefficient, we can also go to the simple linear regression and investigate correlation between two variables that regression coefficients and variance analysis are shown in Table 3.

Table 3. Variance analysis between delegation of authority to managers and financial performance

\begin{tabular}{|c|l|l|l|l|l|c|}
\hline \multirow{2}{*}{ Model } & & $\begin{array}{c}\text { Sum of } \\
\text { Squares }\end{array}$ & \multicolumn{1}{c|}{$\mathrm{df}$} & $\begin{array}{c}\text { Mean } \\
\text { Square }\end{array}$ & F & Sig \\
\hline \multirow{4}{*}{1} & Regression & 49.001 & 1 & 49.001 & \multirow{2}{*}{143.332} & 0.000 \\
\cline { 2 - 6 } & Residual & 50.597 & 148 & 0.342 & & \\
\cline { 2 - 6 } & Total & 99.597 & 149 & & & \\
\hline
\end{tabular}

Above table, regression model variance analysis of $\mathrm{H} 0$ in which slope of the regression line is equal zero. $(F, 143.332)$ with a significance level of 0.000 indicates that the slope of the regression line is not zero. 
Table 4. Regression coefficient between delegation of authority to managers and financial performance

\begin{tabular}{|l|l|l|l|l|l|l|}
\hline \multirow{2}{*}{ Model } & & \multicolumn{2}{|c|}{$\begin{array}{c}\text { Unstandardized } \\
\text { Coefficients }\end{array}$} & $\begin{array}{l}\text { Standardized } \\
\text { Coefficients }\end{array}$ & \multirow{2}{*}{ S } & \\
\cline { 3 - 5 } & & B & Std.Error & Beta & & \\
\hline 1 & (Constant) & 1.426 & 0.227 & 0.701 & 6.281 & 0.000 \\
\cline { 2 - 4 } \cline { 6 - 7 } & $\begin{array}{l}\text { Delegation } \\
\text { of } \\
\text { authority }\end{array}$ & 0.665 & 0.056 & & 11.972 & 0.000 \\
\hline
\end{tabular}

If the delegation of authority to managers in organizations and financial institutions of Guilan province show $\mathrm{X}$ and the financial performance show $\mathrm{Y}$, their relationship is expressed as follows: $\mathrm{Y}=1.426+0.665 \mathrm{X}$

The last column of the above table shows that both factors (ie, the intercept and slope) are significant. Increasing one more unit delegation of authority to managers of organizations and institutions, financial performance, 0.665 unit become higher.

Table 5. Durbin- Watson test between delegation of authority to managers and financial performance

\begin{tabular}{|l|l|l|l|l|l|}
\hline Model & \multicolumn{1}{|c|}{$\mathrm{R}$} & R Square & $\begin{array}{c}\text { Adjusted R } \\
\text { Square }\end{array}$ & $\begin{array}{c}\text { Std.Error } \\
\text { of the } \\
\text { Estimate }\end{array}$ & $\begin{array}{l}\text { Durbin- } \\
\text { Watson }\end{array}$ \\
\hline 1 & 0.701 & 0.492 & 0.489 & 0.58470 & 1.639 \\
\hline
\end{tabular}

The table above reflects the overall situation in which the adjusted $\mathrm{R}$ Square model is the most important indicator. $\mathrm{R}$ square measured 0.489 . It shows the dependent variable explained by the independent variables .Amount of Dubin - Watson is used for investigation of independence of errors (the difference between the actual values and the values predicted by the regression equation). According to the value testing is between 1.5 or 2.5 , so H0 (no correlation between errors) will be accepted.

H2: There is positive and significant relationship between internal communication with the right solutions to improve the efficiency of financial organizations and institutions of Guilan province.

Table 6. Correlation coefficient between internal communication and financial performance

\begin{tabular}{|l|l|l|l|}
\hline \multicolumn{2}{|c|}{} & \multicolumn{1}{c|}{$\begin{array}{c}\text { Internal } \\
\text { communication }\end{array}$} & \multicolumn{1}{c|}{$\begin{array}{c}\text { Financial } \\
\text { performance }\end{array}$} \\
\hline \multirow{2}{*}{$\begin{array}{l}\text { Internal } \\
\text { communication }\end{array}$} & Pearson Correlation & 1 & 0.269 \\
\cline { 2 - 4 } & Sig.(2- tailed) & & 0.001 \\
\cline { 2 - 4 } & $\mathrm{N}$ & 150 & 150 \\
\hline
\end{tabular}

Pearson correlation coefficient of 0.269 with significance level of 0.001 is obtained because the significant level is lower than $0.05, \mathrm{H} 1$ is confirmed. So, there is positive and significant relationship between internal communication with right solutions for efficiency and financial performance in financial organizasions and institusions of Guilan province. Regression coefficients and variance analysis are shown in Table 7. 
Table 7. Variance analysis of internal communication with right solutions and financial performance

\begin{tabular}{|l|l|l|l|l|l|c|}
\hline Model & & \multicolumn{1}{|c|}{$\begin{array}{c}\text { Sum of } \\
\text { Squares }\end{array}$} & \multicolumn{1}{c|}{ df } & $\begin{array}{c}\text { Mean } \\
\text { Square }\end{array}$ & F & Sig \\
\hline \multirow{2}{*}{1} & Regression & 7.202 & 1 & $7 / 202$ & \multirow{2}{*}{11.537} & 0.001 \\
\cline { 2 - 5 } & Residual & 92.395 & 148 & 0.624 & & \\
\cline { 2 - 5 } & Total & 99.597 & 149 & & & \\
\hline
\end{tabular}

Table (7), regression model variance analysis of $\mathrm{H} 0$ in which slope of the regression line is equal zero. (F, 11.537) with a significance level of 0.001 indicates that the slope of the regression line is not zero.

Table 8. Regression coefficients between internal communication and financial performance

\begin{tabular}{|l|l|l|l|l|l|l|}
\hline \multirow{2}{*}{ Model } & & \multicolumn{2}{c|}{$\begin{array}{c}\text { Unstandardized } \\
\text { Coefficients }\end{array}$} & $\begin{array}{l}\text { Standardized } \\
\text { Coefficients }\end{array}$ & \multirow{2}{*}{ S } & \\
\cline { 3 - 5 } & & B & Std.Error & Beta & & \\
\hline \multirow{2}{*}{1} & (Constant) & 2.871 & 0.363 & 0.269 & 7.918 & 0.000 \\
\cline { 2 - 4 } & $\begin{array}{l}\text { Internal } \\
\text { communication }\end{array}$ & 0.314 & 0.093 & & 3.397 & 0.001 \\
\hline
\end{tabular}

If internal communications with right solutions for efficiency in organizations and financial institutions of Guilan province show $\mathrm{X}$ and the financial performance show $\mathrm{Y}$, their relationship is expressed as follows:

$\mathrm{Y}=\mathbf{2 . 7 8 1}+\mathbf{0 . 3 1 4 X}$

The last column of the above table shows that both factors (ie, the intercept and slope) are significant. Increasing one more unit internal communicationsfor efficiency of organizations and institutions of Guilan province, financial performance, 0.314 unit become higher.

Table 9. Durbin- Watson test between internal communication and financial performance

\begin{tabular}{|l|l|l|l|l|l|}
\hline Model & \multicolumn{1}{|c|}{$\mathrm{R}$} & $\mathrm{R}$ Square & $\begin{array}{c}\text { Adjusted R } \\
\text { Square }\end{array}$ & $\begin{array}{c}\text { Std.Error } \\
\text { of the } \\
\text { Estimate }\end{array}$ & $\begin{array}{l}\text { Durbin- } \\
\text { Watson }\end{array}$ \\
\hline 1 & 0.269 & 0.072 & 0.066 & 0.79012 & 1.871 \\
\hline
\end{tabular}

The table (9) reflects the overall situation in which the adjusted R Square model is the most important indicator. $\mathrm{R}$ square measured 6.6. It shows the dependent variable explained by the independent variables.Amount of Dubin - Watson is used for investigation of independence of errors (the difference between the actual values and the values predicted by the regression equation). According to the value testing is between 1.5 or 2.5 , so $\mathrm{H} 0$ (no correlation between errors) will be accepted.

\section{H3: There is positive relationship between participation of employees in decision-making with financial performance in financial organizations and institutions of Guilan province.}

Table 10. Correlation coefficient between employees participation and financial performance

\begin{tabular}{|l|l|l|l|}
\hline \multicolumn{2}{|c|}{} & \multicolumn{1}{|c|}{$\begin{array}{c}\text { Employees } \\
\text { participation }\end{array}$} & \multicolumn{1}{c|}{$\begin{array}{c}\text { Financial } \\
\text { performance }\end{array}$} \\
\hline \multirow{2}{*}{$\begin{array}{l}\text { Employees } \\
\text { participation }\end{array}$} & Pearson Correlation & 1 & 0.277 \\
\cline { 2 - 4 } & Sig.(2- tailed) & & 0.001 \\
\cline { 2 - 4 } & $\mathrm{N}$ & 150 & 150 \\
\hline
\end{tabular}


Pearson correlation coefficient of 0.277 with significance level of 0.001 is obtained because the significant level is lower than $0.05, \mathrm{H} 1$ is confirmed. So, there is positive and significant relationship between employees participation in deciesion making and financial performance in financial organizasions and institusions of Guilan province. Regression coefficients and variance analysis are shown in Table 11.

Table 11. Variance analysis of employees participatin in decision- making and financial

\begin{tabular}{|c|c|c|c|c|c|c|}
\hline Model & & $\begin{array}{l}\text { Sum of } \\
\text { Squares }\end{array}$ & Df & $\begin{array}{l}\text { Mean } \\
\text { Square }\end{array}$ & $\mathrm{F}$ & Sig \\
\hline \multirow[t]{3}{*}{1} & Regression & 7.656 & 1 & 7.656 & \multirow[t]{3}{*}{12.323} & \multirow[t]{3}{*}{0.001} \\
\hline & Residual & 91.942 & 148 & 0.621 & & \\
\hline & Total & 99.597 & 149 & & & \\
\hline
\end{tabular}

Above table, regression model variance analysis of $\mathrm{H} 0$ in which slope of the regression line is equal zero. $(F, 12.323)$ with a significance level of 0.001 indicates that the slope of the regression line is not zero.

Table 12. Regression coefficients between employees participatin in decision- making and financial performance

\begin{tabular}{|c|c|c|c|c|c|c|}
\hline \multirow[t]{2}{*}{ Model } & & \multicolumn{2}{|c|}{$\begin{array}{l}\text { Unstandardized } \\
\text { Coefficients }\end{array}$} & $\begin{array}{l}\text { Standardized } \\
\text { Coefficients }\end{array}$ & \multirow[t]{2}{*}{$\mathrm{T}$} & \multirow[t]{2}{*}{ Sig } \\
\hline & & B & Std.Error & Beta & & \\
\hline \multirow[t]{2}{*}{1} & (Constant) & 2.856 & 0.353 & \multirow[t]{2}{*}{0.277} & 8.119 & 0.000 \\
\hline & $\begin{array}{l}\text { Employees } \\
\text { participation }\end{array}$ & 0.315 & 0.090 & & 3.510 & 0.000 \\
\hline
\end{tabular}

If employees participation in organizations and financial institutions of Guilan province show $\mathrm{X}$ and the financial performance show $\mathrm{Y}$, their relationship is expressed as follows:

$Y=\mathbf{2 . 8 5 6}+\mathbf{0 . 3 1 5 X}$

The last column of the above table shows that both factors (ie, the intercept and slope) are significant. Increasing one more unit rmployees participation of organizations and institutions of Guilan province, financial performance become 0.315 unit higher.

Table 13. Durbin- Watson test between employees participatin in decision- making and financial performance

\begin{tabular}{|l|l|l|l|l|l|}
\hline Model & $\mathrm{R}$ & $\mathrm{R}$ Square & $\begin{array}{c}\text { Adjusted R } \\
\text { Square }\end{array}$ & $\begin{array}{c}\text { Std.Error } \\
\text { of the } \\
\text { Estimate }\end{array}$ & $\begin{array}{c}\text { Durbin- } \\
\text { Watson }\end{array}$ \\
\hline 1 & 0.277 & 0.077 & 0.071 & 0.78818 & 1.527 \\
\hline
\end{tabular}

The table above reflects the overall situation in which the adjusted $\mathrm{R}$ Square model is the most important indicator. $\mathrm{R}$ square measured 7.1. It shows the dependent variable explained by the independent variables .Amount of Dubin - Watson is used for investigation of independence of errors (the difference between the actual values and the values predicted by the regression equation). According to the value testing is between 1.5 or 2.5, so $\mathrm{H} 0$ (no correlation between errors) will be accepted. 


\section{H4: There is positive relationship between flexibility and financial performance in financial organizations and institutions of Guilan province}

Table 14. Correlation coefficient between flexibility and financial performance

\begin{tabular}{|l|l|l|l|}
\hline \multicolumn{2}{|c|}{} & Flexibility & \multicolumn{1}{|c|}{ Financial performance } \\
\hline Flexibility & Pearson Correlation & 1 & 0.704 \\
\cline { 2 - 4 } & Sig.(2- tailed) & & 0.000 \\
\cline { 2 - 4 } & N & 150 & 150 \\
\hline
\end{tabular}

Pearson correlation coefficient of 0.704 with significance level of 0.000 is obtained because the significant level is lower than $0.05, \mathrm{H} 1$ is confirmed. So, there is positive and significant relationship between flexibility with financial performance in financial organizasions and institusions of Guilan province. After calculating the correlation coefficient, we can also go to the simple linear regression and investigate correlation between two variables that regression coefficients and variance analysis are shown in Table 15.

Table 15. Variance analysis of flexibility with financial performance

\begin{tabular}{|l|l|l|l|l|l|l|}
\hline Model & & \multicolumn{1}{c|}{$\begin{array}{c}\text { Sum of } \\
\text { Squares }\end{array}$} & \multicolumn{1}{c|}{ Df } & $\begin{array}{c}\text { Mean } \\
\text { Square }\end{array}$ & F & Sig \\
\hline \multirow{2}{*}{1} & Regression & 49.296 & 1 & 49.296 & \multirow{2}{*}{145.045} & 0.000 \\
\cline { 2 - 7 } & Residual & 50.301 & 148 & 0.340 & & \\
\cline { 2 - 7 } & Total & 99.597 & 149 & & & \\
\hline
\end{tabular}

Above table, regression model variance analysis of $\mathrm{H} 0$ in which slope of the regression line is equal zero. (F, 145.045) with a significance level of 0.000 indicates that the slope of the regression line is not zero.

Table 16. Regression coefficients between flexibility and financial performance

\begin{tabular}{|l|l|l|l|l|l|l|}
\hline \multirow{2}{*}{ Model } & & \multicolumn{2}{|c|}{$\begin{array}{c}\text { Unstandardized } \\
\text { Coefficients }\end{array}$} & $\begin{array}{l}\text { Standardized } \\
\text { Coefficients }\end{array}$ & \multirow{2}{*}{ Sig } & \\
\cline { 3 - 5 } & & $\mathrm{B}$ & Std.Error & Beta & & \\
\hline \multirow{2}{*}{1} & (Constant) & 1.206 & 0.244 & 0.704 & 4.95 & 0.000 \\
\cline { 2 - 4 } \cline { 3 - 4 } & Flexibility & 0.698 & 0.058 & & 12.043 & 0.000 \\
\hline
\end{tabular}

If the delegation of authority to managers in organizations and financial institutions of Guilan province show $\mathrm{X}$ and the financial performance show $\mathrm{Y}$, their relationship is expressed as follows:

$Y=1.206+0.698 X$

The last column of the above table shows that both factors (ie, the intercept and slope) are significant. Increasing one more unit delegation of authority to managers of organizations and institutions, financial performance become 0.698 unit higher.

Table 17. Durbin- Watson test between flexibility and financial performance

\begin{tabular}{|c|c|l|l|l|l|}
\hline Model & $\mathrm{R}$ & $\mathrm{R}$ Square & $\begin{array}{c}\text { Adjusted R } \\
\text { Square }\end{array}$ & $\begin{array}{c}\text { Std.Error of } \\
\text { the Estimate }\end{array}$ & $\begin{array}{c}\text { Durbin- } \\
\text { Watson }\end{array}$ \\
\hline 1 & 0.704 & 0.495 & 0.492 & 0.58298 & 1.706 \\
\hline
\end{tabular}

The table above reflects the overall situation in which the adjusted $\mathrm{R}$ Square model is the most important indicator. $\mathrm{R}$ square measured 49.2. It shows the dependent variable explained by the independent variables. Amount of Dubin - Watson is used for investigation of independence of errors (the difference between the actual values and the values predicted by the regression equation). According to the value testing is between 1.5 or 2.5 , so $\mathrm{H} 0$ (no correlation between errors) will be accepted. 


\section{H5: There is positive relationship between supportive management and financial performance in financial organizations institutions of Guilan province.}

Table 18. Correlation coefficient between supportive management and financial performance

\begin{tabular}{|l|l|l|l|}
\hline \multicolumn{2}{|c|}{} & \multicolumn{1}{|c|}{$\begin{array}{c}\text { Supportive } \\
\text { Management }\end{array}$} & \multicolumn{1}{c|}{$\begin{array}{c}\text { Financial } \\
\text { performance }\end{array}$} \\
\hline \multirow{2}{*}{$\begin{array}{l}\text { Supportive } \\
\text { Management }\end{array}$} & Pearson Correlation & 1 & 0.598 \\
\cline { 2 - 4 } & Sig.(2- tailed) & & 0.000 \\
\cline { 2 - 4 } & $\mathrm{N}$ & 150 & 150 \\
\hline
\end{tabular}

Pearson correlation coefficient of 0.598 with significance level of 0.000 is obtained because the significant level is lower than $0.05, \mathrm{H} 1$ is confirmed. So, there is positive and significant relationship between supportive management and financial performance in financial organizasions and institusions of Guilan province. After calculating the correlation coefficient, we can also go to the simple linear regression and investigate correlation between two variables that regression coefficients and variance analysis are shown in Table 19.

Table 19. Variance analysis of supportive management with financial performance

\begin{tabular}{|l|l|l|l|l|l|l|}
\hline \multicolumn{1}{|c|}{ Model } & & Sum of Squares & \multicolumn{1}{c|}{ df } & Mean Square & F & Sig \\
\hline \multirow{4}{*}{1} & Regression & 35.643 & 1 & 35.643 & 82.483 & 0.000 \\
\cline { 2 - 5 } & Residual & 63.954 & 148 & 0.432 & & \\
\cline { 2 - 5 } & Total & 99.597 & 149 & & & \\
\hline
\end{tabular}

Above table, regression model variance analysis of $\mathrm{H} 0$ in which slope of the regression line is equal zero. (F, 82.483) with a significance level of 0.000 indicates that the slope of the regression line is not zero.

Table 20. Regression coefficients between supportive management and financial performance

\begin{tabular}{|l|l|l|l|l|l|l|}
\hline \multirow{2}{*}{ Model } & & \multicolumn{2}{|c|}{$\begin{array}{c}\text { Unstandardized } \\
\text { Coefficients }\end{array}$} & $\begin{array}{l}\text { Standardized } \\
\text { Coefficients }\end{array}$ & \multirow{2}{*}{ Sig } \\
\cline { 3 - 5 } & & $\mathrm{B}$ & Std.Error & Beta & \\
\hline \multirow{2}{*}{1} & (Constant) & 1.877 & 0.249 & 0.598 & 7.456 & 0.000 \\
\cline { 2 - 4 } \cline { 3 - 4 } & $\begin{array}{l}\text { Supportive } \\
\text { Management }\end{array}$ & 0.523 & 0.058 & & 9.082 & 0.000 \\
\hline
\end{tabular}

If the delegation of authority to managers in organizations and financial institutions of Guilan province show $\mathrm{X}$ and the financial performance show $\mathrm{Y}$, their relationship is expressed as follows: $\mathrm{Y}=1.877+0.523 \mathrm{X}$

The last column of the above table shows that both factors (ie, the intercept and slope) are significant. Increasing one more unit supportive managementof organizations and institutions, financial performance become 0.523 unit higher.

Table 21. Durbin- Watson test between supportive management and financial performance

\begin{tabular}{|c|c|l|l|l|l|}
\hline Model & \multicolumn{1}{|c|}{$\mathrm{R}$} & $\mathrm{R}$ Square & $\begin{array}{c}\text { Adjusted R } \\
\text { Square }\end{array}$ & $\begin{array}{c}\text { Std.Error of } \\
\text { the Estimate }\end{array}$ & $\begin{array}{l}\text { Durbin- } \\
\text { Watson }\end{array}$ \\
\hline 1 & 0.598 & 0.358 & 0.354 & 0.65736 & 1.77 \\
\hline
\end{tabular}

The table above reflects the overall situation in which the adjusted $\mathrm{R}$ Square model is the most important indicator. $\mathrm{R}$ square measured 35.4. It shows the dependent variable explained by the independent variables. Amount of Durbin- Watson is used for evaluating the error (difference between actual value and the value predicted by the regression equation). Since the amount of the test is between 1.5 or 2.5 , so the $\mathrm{H} 0$ (no correlation between errors) will be accepted. 


\section{MULTIPLE REGRESSION}

Multiple Regression of model is provided for competitive advantages and independent variables in order to measure financial performanc with other independent vatiables. Multiple linear regression (step 1) is used for relationships between variables. In the method of stepwise regression variables, only variables are remained that lonely and with other variables are significant. Multiple regression model as follows.

$\mathrm{Y}=\alpha+\beta_{1} X_{1}+\beta_{2} X_{2}+\ldots . .+\beta_{k} X_{k}+\varepsilon$

$\alpha$ is constant or intercept, $\beta$ is regression coefficients and $\varepsilon$ is the error. $X$ and $Y$ are dependent and independent variable. Table of regression model show only significant variables.

Table 22. Multiple regression between variables

\begin{tabular}{|c|c|c|c|c|}
\hline \multirow[t]{3}{*}{$\mathrm{R}$ squared } & coefficients & \multirow[t]{3}{*}{ Sig } & \multirow{3}{*}{$\begin{array}{l}\text { Independent } \\
\text { variables }\end{array}$} & \multirow{3}{*}{$\begin{array}{l}\text { Dependent } \\
\text { variable }\end{array}$} \\
\hline & Beta & & & \\
\hline & Constant $=0.625$ & & & \\
\hline \multirow[t]{5}{*}{0.603} & 0.326 & 0.000 & $\begin{array}{l}\text { Delegation of } \\
\text { authority }\end{array}$ & \multirow[t]{5}{*}{$\begin{array}{c}\text { Financial } \\
\text { performance }\end{array}$} \\
\hline & ------ & 0.198 & $\begin{array}{l}\text { Internal } \\
\text { communications }\end{array}$ & \\
\hline & $\begin{array}{l}---- \\
\end{array}$ & 0.230 & $\begin{array}{l}\text { Employees } \\
\text { participation }\end{array}$ & \\
\hline & 0.303 & 0.000 & Flexibility & \\
\hline & 0.215 & 0.000 & $\begin{array}{l}\text { Supportive } \\
\text { management }\end{array}$ & \\
\hline
\end{tabular}

As shown in Table 22, the significance level for variables of delegation of authority, flexibility and supportive management are less than 0.05 that showed there is a linear relationship between the above factors and financial performance. On the other hand, sig value for the variable of internal communication and employees participation is more than 0.05 , which reflects the lack of a linear relationship between the above factors and financial performance. $\mathrm{R}$ squered of model is equal to 0.603 . Equation regression line as follows:

$\mathrm{Y}=0.625+0.326+0.303 \mathrm{X} 4+0.215 \mathrm{X} 5$

\section{Friedman test}

Friedman test was used to examine the same prioritization of independent variables (Momeni and Qayyum, 1391). So Friedman nonparametric test was used to compare the mean scores of social responsibility in this section. Friedman test hypotheses for this study is as follows:

$\mathrm{H} 0$ : There is no difference between the dimensions of social responsibility in terms of importance.

$\mathrm{H} 1$ : There is a difference between the dimensions of social responsibility in terms of importance.

Table 23. Ranking of variables

\begin{tabular}{|l|l|}
\hline Variables & Maen of ranking \\
\hline Supportive management & 3.53 \\
\hline Flexibility & 3.30 \\
\hline Delegation of authority & 2.98 \\
\hline Employees participation & 2.60 \\
\hline Internal communication & 2.25 \\
\hline
\end{tabular}

According to the rating of dimentions of social responsibility, supportive management is known with an mean rating of respondents aquel to 3.53. Then, flexibility with an mean rating of 3.30 was calculated as the second important factor. Delegation, participation and internal communications were followed respectively. 
Table24. Friedman Test

\begin{tabular}{|c|c|}
\hline $\mathrm{N}$ & 150 \\
\hline Chi-Square & 46.2 \\
\hline Df & 4 \\
\hline Asymp.Sig & 0.000 \\
\hline
\end{tabular}

The result of this test with the chi-square test statistic equal to 46.2 and 5 percent level of error is significant. Thus, H1 is confirmed.

\section{CONCLUSION}

The relationship between the two variables delegation and financial performance of the organizations and institutions was 0.701 and the significance level was zero. Based on this analysis, amount of R squere can be made as follows: 48.9 per cent of the variability in the performance of financial delegation is explained by the independent variable of delegation . The results of this hypothesis is consistent with the results of Ahmad et al. (2012) and Abrunhosa and Sa (2008). The relationship between the two variables to internal communications and financial performance of organizations and institutions was 0.269 . There is a significant positive relationship between the right solutions to improve the efficiency of internal communication in organizations and financial performance of organizationss of Guilan province. Based on this analysis, R squeare can be made as follows: $6.6 \%$ of the variability in financial performance, internal communications can be explained by the independent variable. The result of this hypothesis is consistent the results of Ahmad et al (2012) and Abrunhosa and Sa (2008).The relationship between two variables of employees participation in decision-making and financial performance of organizations and institutions was 0.277 and the significant level equal to 0.001 . The result of this hypothesis is consistent with the results of Ahmad et al. (2012) and Abrunhosa and Sa (2008).

The relationship between the two variables of flexibility and financial performance of organizations and institutions was 0.704 and the significant level of zero is obtained. According to $\mathrm{R}$ squered analyezed as follow: Relationship between two variables of supportive management style and financial performance of organizations and institutions was 0.598 and the significant level of zero is obtained. There is a significant and positive relationship between supportive management style and financial performance in organizations and financial institutions of Guilan province. Based on this analysis, R squeare can be made as follows: 42.4 percent of the variability in financial performance, supportive management style can be explained by the independent variable. The result of this hypothesis is consistent with the results of research and other and Abrunhosa and Sa (2008).

\section{Suggestions}

- Conducting assessment of training for those management involved in the tasks and delegated activities.

- Reviewing the regulations and demystification of delegation.

-More mental communication by managers with staff.

- Establishment of a proper process ofsuggestions regarding to the input and output process.

- Create a supportive atmosphere and environment for the employees from organization's managers.

- Allowing competent staff and specializes in designing activites related to their branch.

- Use the proper patterns of flexibility with regard to the number of managers, environmental and competitive market.

- Use the same methods of funding to eliminate the financial needs.

\section{Limitations}

In this section some restrictions researcher will provide :

- Conceptual model of research tested only in the financial organizations of Guilan province, so it should be extended to other agencies must act with caution. 
- The population of the geographical location was Guilan province so the testing leads to different results in different areas.

- The research performed over a period of six months in 1393, with the passage of time results may have changed the results of new research.

- Given that financial institutions are Gilan profit organization, it may be the result of research can be generalized to other organizations.

- Dimensions of social responsibility in the conceptual model consisted of 5 variables. This five variables may not reflect all aspects of social responsibility in the financial institutions of Guilan.

- Lack of cooperation and lack of precision in some of the respondents to answer questions.

\section{Future suggestions}

- Testing conceptual model of research in other private organizations and compare the results obtained with this research.

- Testing the conceptual model of research in financial organizations of other provinces.

- Comparative study of the model in two private organizations simultaneously.

- Conducting similar research in different time periods to assess the results of research.

- Consideration of other variables to clarify the issue of social responsibility.

- Testing model the of research in the manufacturing industry for more generalizability research result.

\section{References}

[1]. Badavar nahandi Younes, Baradaran hasan zadeh Rasool, Jalalifar,Shila. Investigating relationship between social responsibility and performance of accepted companies in stock exchange of Tehran,Productivity management, 1393,28,139-164.

[2]. Pourali Mohammadreza, Hajami Mohaddese. Investigating relationship between disclosure of social responsibility and institutional ownership in accepted companies in stock exchange of Tehran, Quarterly scientific research of accounting knowledge management audit,1393, 3,10, 135-150.

[3]. Heydariyan Behnam(1389). investigating impact of industry structure on social responsibility of company, Thesis of M.A. university of Tabriz.

[4]. Senobar Naser, Khalili Majid, Saghafiyan Hamed, Investigating relationship between social responsibility and financial performance of companies, Quarterly scientific research of exploring business management, 1390,2,4,28-52.

[5]. Arab salehi Mehdi, Sadeghi Ghazal, Moein oldin Mahmood, relationship between social responsibility and performance of accepted companies stock exchange of Tehran, Psychiatry and Behavioral sciences, 1392,3,9,1-20.

[6]. Ghari Raziyeh, social responsibility of organization and necessity of it,Bulletin of social responsibility of organizations (3), 1389,109-157.

[7]. Yazdani Ayoob, (1388), investigating relationship environmental efficacy value and output of assets of accepted companies in stock exchange of Tehran, Thesis of M.A. university of Tabriz.

[8]. Ahmed Sarwar Uddin, Islam Md. Zahidul, Hasan Ikramul. Corporate Social Responsibility an Financial Performance Linkage- Evidence from the Banking Sector of Banglasesh, Journal of Organizational Management, 2012, 1,14- 21.

[9]. Chen D N, Liang T-p. Knowledge evolution strategies and organizational.

[10]. Fauzi Hasan, Ldris Kamil, The relationship of CRS and financial performance, Journal of management, 2010, 1 , 467-479. 
[11]. Flammer Caroline, Does Corporate Social Relationship Lead to Superier Financial Performance? MIT Sloan Shool of Management, 2013, 2, 2 ,2 - 22.

[12]. Kawal Munaza, Khanam Faarida, Nasereen Shagufla, Hameed Shahid," Impact of Corporate Social Responsibility on the firm's financial Performance", Journal of Business and Management ",2013,31,1-10.

[13]. Lee, Y.C., Lee, M.L., Yen, T. M., \& Huang, T.H" Analasis of fuzzy Decision Making Trial and Evaluation Laboratory on technology acceptance model", Expert Systems with Applications, 2011, 31,1-10

[14]. Mohr Lois A, Webb Deborah J, "The effect of corporate social responsibility and price on consumer responses", Journal of Consumer Affairs,2005,39,1,121-147.

[15]. Pan Xiping, Sha Jinghua, Zhang Hongilang," Relationship between corporate social responsibility anf financial performance in the mineral industry", Sudtainability, 2014,6,40774101.

[16]. Smy Martin, Odemilin Godwin, Bampton Roberta, "Coporate social responsibility: a strategy for sustainable business success. An analysis of 20 selected British companies", Journal of corporate governance,2010,10,2,203-217.

[17]. Sandhu H S, Kapoor Shveta,"Corporate social responsibility initiatives: An analysis of voluntry corporate disclosure", South Asian Journal of Management, 2010, 17,2,47-80.

[18]. Santos-Vijande M.L,Lopez-Sanchez J, respalacio J."How organizational learning affects a firms flexibility, competitive strategy and performance".Journal of business research 2011,10,18-32.

[19]. Simpson W. Gary, Kohers Theodor,"The link between corporate social and financial performance:evidence from the banking industry",Journal of Business ethics, 2002,35,297-109.

[20]. Tsoutsoura Margarita,(2004),"Corporate social responsibility and financial performanc", University of California at Berkeley, financial project.

[21]. Wang Zhining, Wang Nianxin, Liang Huigang," Knowledge sharing, intellectual capital and firm performance", Management Decisions, 2014,52,2,230-258. 